\title{
Cytophaga sp. (Cytophagales) infection in seawater pen-reared Atlantic salmon Salmo salar
}

\author{
Michael L. Kent ${ }^{1}$, Christopher F. Dungan ${ }^{1}$, Ralph A. Elston ${ }^{1}{ }^{\text {, Richard A. Holt }}{ }^{2}$ \\ ${ }^{2}$ Battelle Marine Research Laboratory, 439 West Sequim Bay Rd, Sequim, Washington 98382, USA \\ ${ }^{2}$ Department of Microbiology, Oregon State University, Corvalis, Oregon 97331, USA
}

\begin{abstract}
A Cytophaga sp. was associated with skin and muscle lesions of moribund Atlantic salmon Salmo salar smolts shortly after they were introduced to seawater in the late winter and spring of 1985 , 1986, and 1987. Concurrent with high mortalities, the lesions were most prevalent 1 wk after introduction. Fish introduced to seawater in summer were less severely affected. The lesions initially appeared as white patches on the flanks in the posterior region, and, as the disease progressed, enlarged and extended deep into the underlying muscle. Fish with the lesions exhibited elevated plasma sodium levels, and a probable cause of mortality was osmotic stress. Wet mounts of the lesions from all epizootics revealed numerous filamentous gliding bacteria. Gliding bacteria were isolated on Marine Agar and on seawater Cytophaga Medium from samples obtained during the 1987 epizootics, and were identified as a Cytophaga sp. based on biochemical, morphological, and $G+C$ ratio data. The organism is a marine bacterium requiring at least $10 \%$ seawater for growth in Cytophaga Medium. In addition to differences in growth characteristics, this isolate was serologically distinct from C. psychrophila, Flexibacter columnaris, and F. maritimus. We have experimentally induced the lesions in Atlantic salmon smolts with a pure culture of the organism, thus supporting the hypothesis that the Cytophaga sp. described here is the etiological agent of the disease.
\end{abstract}

\section{INTRODUCTION}

Cytophaga and Flexibacter spp. (order Cytophagales) are important bacterial pathogens of cultured fishes and typically cause external lesions in freshwater and marine species (Anderson \& Conroy 1969, Pacha \& Ordal 1970). Flexibacter columnaris and C. psychrophila are well-recognized pathogens of fishes reared in freshwater (Becker \& Fujihara 1978, Pacha \& Ordal 1970, Sniesko \& Bullock 1976), and F, maritimus causes mortality in marine fishes such as cultured flounder Paralichthys olivaceous (Baxa et al. 1986) and various species of sea bream (Pagrus major, Acanthopagrus schlegeli and Oplegnathus fasciatus) (Masumura \& Wakabayashi 1977, Hikida et al. 1979, Wakabayashi et al. 1984, 1986, Baxa et al. 1987). Another CytophagaFlexibacter-like (C-F) bacterium was shown experimentally to cause black patch necrosis in Dover sole Solea solea (Campbell \& Buswell 1982). Although this bacterium infected a marine fish the authors described it as most similar to the freshwater pathogen $F$. columnaris.
Less well described C-F bacteria have been reported in salmonid fishes cultured in seawater. External lesions in cultured chinook salmon Oncorhynchus tshawtyscha associated with C-F bacteria were reported by Rucker (1963), and diseases associated with C-F bacteria were reported in seawater-reared pink salmon $O$. gorbuscha (Borg 1960), coho salmon O. kisutch (Sawyer 1976), and rainbow trout Salmo gairdneri (Anderson \& Conroy 1969). Bacteria assigned to the genus Sporocytophaga were associated with large skin lesions on coho, chinook, and sockeye salmon (O. nerka), and steelhead trout (Salmo gairdneri) (Wood 1974).

Culture of Atlantic salmon (Salmo salar) in seawater pens is an important industry in Europe and is now rapidly expanding in North America. We report here pathological changes and mortality associated with a seasonal Cytophaga infection in Atlantic salmon smolts maintained in net pens in the Strait of Juan de Fuca on the coast of Washington State, USA. Some morphological, serological, cultural transmission, and biochemical data on a species of Cytophaga isolated from skin and muscle lesions are presented 


\section{MATERIALS AND METHODS}

Clinical and histological observations. Atlantic salmon examined in this study were reared from eggs at a freshwater hatchery in Washington State and transferred as smolts to seawater net pens. Although the disease was observed in many pens at one farm site, one pen was studied in-depth during the 1986 epizootic to characterize the progression of the disease. On 7 March 1986, 6286 smolts (mean wt $65 \mathrm{~g}$ ) were introduced to the pen. Water temperature was 8 to $10^{\circ} \mathrm{C}$ and salinity was 30 to 32 ppt during the epizootic.

Fish were examined 1,6 , and $13 \mathrm{~d}$ post-introduction (PI). Plasma for sodium analysis was obtained from moribund fish with skin lesions and from asymptomatic fish from the same pen by sevenng the caudai peduncle and collecting blood in lithium heparinized tubes. Plasma sodium concentrations were determined by atomic absorption flame spectrophotometry. Mortality data were recorded by hatchery personnel. Wet mounts of scrapings from lesions were examined by Nomarski's phase interference microscopy. Internal gross examinations were performed on affected fish, and the gills, visceral organs, skin, and underlying muscle of 10 affected fish collected $13 \mathrm{~d}$ PI were examined histologically. Tissues were fixed in Davidson's solution (Humason 1979) and processed using standard techniques.

Bacterial characteristics. Bacteria were cultured by disinfecting lesion surfaces with $70 \%$ ethanol and obtaining inocula from deep within lesions during the 1987 epizootic. Inocula were cultured at room temperature and at $10^{\circ} \mathrm{C}$ on Cytophaga Medium (Anacker \& Ordal 1959) made with $50 \%$ seawater and on Marine Agar (Difco). Kidney inocula were aseptically obtained from 10 affected fish collected $6 \mathrm{~d} P \mathrm{PI}_{\text {; }}$ they were streaked on sheep blood agar and incubated at room temperature

Antisera against Flexibacter maritimus, F. columnaris, and Cytophaga psychrophila were tested for cross reaction with a representative isolate obtained in this study using Ouchterlony gel diffusion preparations as described by Elston et al. (1982). Antiserum to $F$. maritimus was provided by $\mathrm{H}$. Wakabayashi, University of Tokyo, Japan, and antisera to the 2 other bacteria were obtained from the Fish Disease Laboratory, Department of Microbiology, Oregon State University, Corvallis, Oregon, USA. Soluble antigen for the test was prepared from our isolate by sonication as described by Elston et al. (1982).

The concentration of seawater required for growth was determined by adding seawater at 10,20,30,50, and $100 \%(\mathrm{v} / \mathrm{v})$ to Cytophaga Medium. The temperature range for growth was determined by culturing bacteria on Marine Agar at $4{ }^{\circ} \mathrm{C}$ and in $5 \mathrm{C}^{\circ}$ increments from 10 to $40^{\circ} \mathrm{C}$. Gliding motility was observed in wet mount preparations. Production of flexirubin was assessed by adding $20 \%(\mathrm{w} / \mathrm{v}) \mathrm{KOH}$ to young colonies on Marine Agar plates and observing them for the development of a purple or violet pigment. The production of oxidase was determined with Cepbi-seal oxidase reagent (Marion Scientific, Kansas City, Missouri, USA). The DNA base composition was determined using a hydroxylapatite method as described by Johnson (1981). The ability to form microcysts was investigated by observing cultures incubated for 3 wk. Other biochemical tests used standard methods as described by Smibert \& Krieg (1981)

Transmission. A transmission experiment was conducted to determine the pathogenicity of our isolate. Thirty Atlantic salmon smolts were transferred to the Battelie Miarine Ldboratury, Sequim, Washington, from a freshwater hatchery. Fish were introduced to open system seawater aquaria. The affluent water was sandfiltered, and the water in the aquaria was maintained at $11^{\circ} \mathrm{C}$. After $6 \mathrm{~h}$ acclimation, the fish were anesthetized with MS-222 and the skin at the caudal peduncle was lightly abraded with a sterile scalpel blade. Heavy inocula of the isolate (designated SF87-16c), which had been passed twice in vitro since original isolation, were swabbed on the scarified regions of 10 fish. To determine if agents other than the isolated bacterium were required to induce the lesions, 10 additional fish were treated similarly, except that the scarified regions were swabbed with fresh lesion material obtained from a fish with a prominent muscle lesion. Ten additional fish with scarified peduncles were maintained as controls.

\section{RESULTS}

\section{Clinical observations}

At the time of introduction into seawater, some of the fish exhibited frayed fins and scale loss. These abnormalities were attributed to transport trauma and 185 $(2.9 \%)$ of the affected fish died within $2 \mathrm{~d}$ of introduction (Fig. 1). However, none of these fish exhibited the body lesions as described below. At $4 \mathrm{~d}$ PI, the mortality rate began to increase and peaked at 6 to $7 \mathrm{~d}$ PI. At this time, moribund fish exhibited large, white patches on the caudal peduncle and posterior region of the flanks. In some of these fish the dermis still appeared intact. In other fish, the lesions were more severe; the skin was absent and the underlying muscle was exposed (Fig. 2), Wet mount examinations of the lesions material collected during the 1985, 1986, and 1987 epizootics revealed masses of filamentous bacteria which exhibited gliding motility.

At $13 \mathrm{~d}$ PI, fish with the skin lesions continued to die (Fig. 1), and wet mount examinations of the lesions 
Fig. 1. Salmo salar. Mortality in Atlantic salmon smolts with Cytophaga infections following introduction to seawater, March 1986

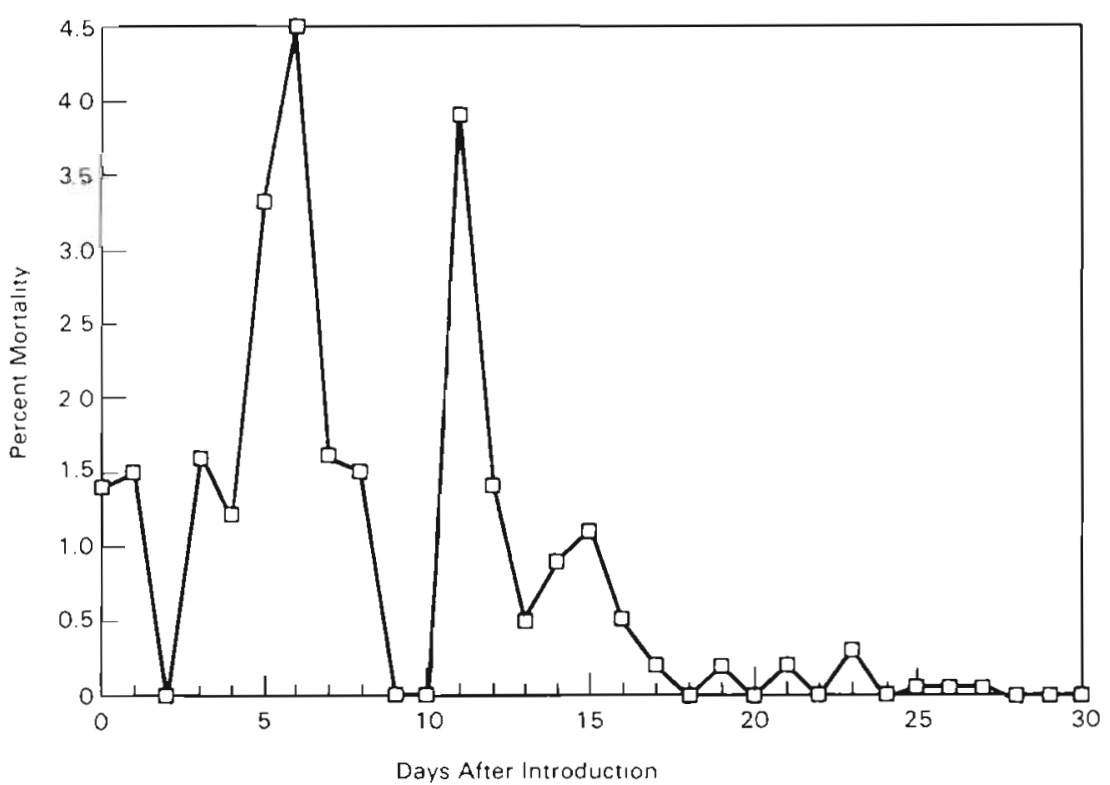

Days After Introduction

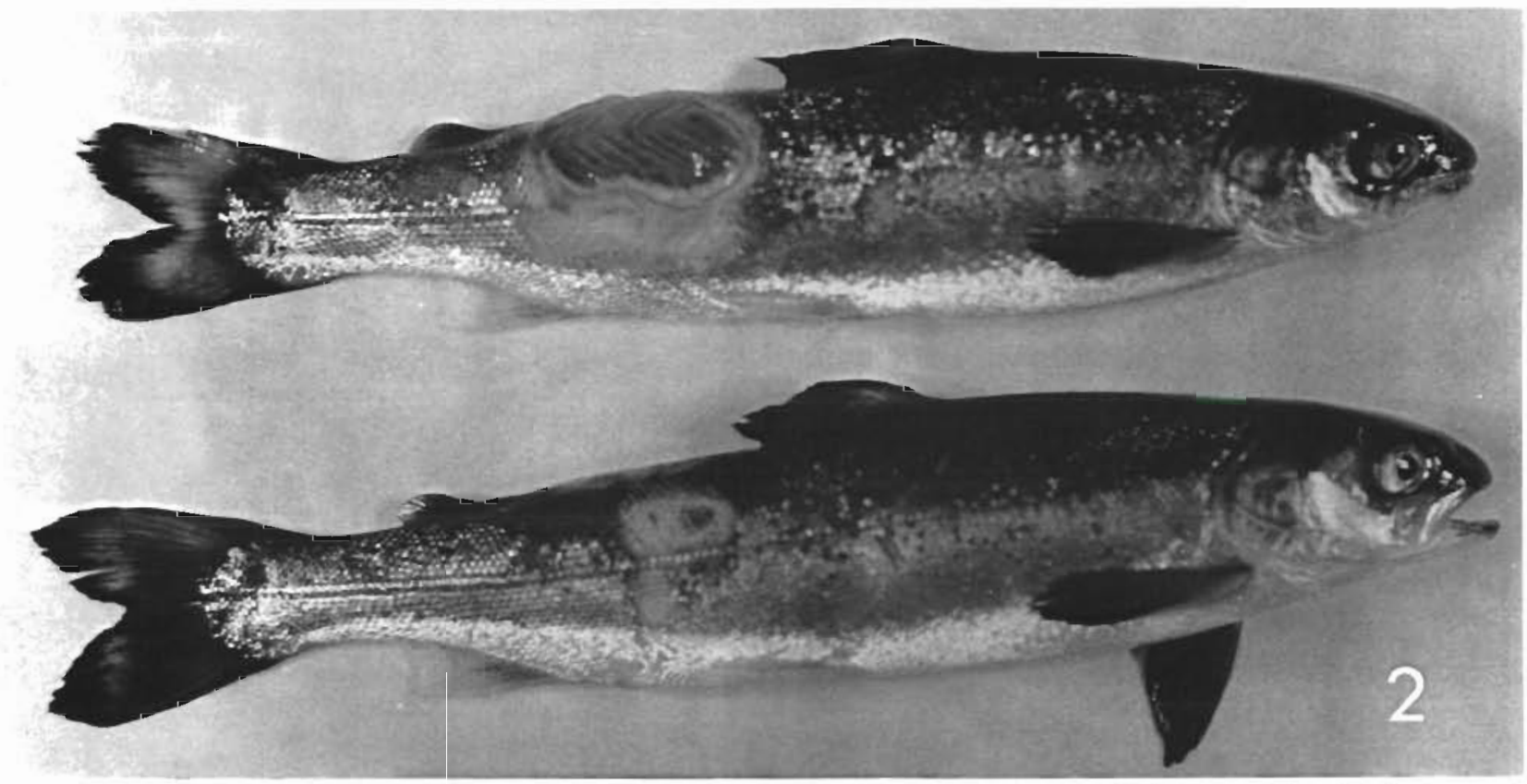

Fig. 2. Salmo salar. Skin and muscle lesions in Atlantic salmon smolts with Cytophaga infections. The lower fish exhibited an early lesion consisting of a white patch on the posterior flank associated with a loss of scales and epidermis. The upper fish exhibited an advanced lesion consisting of a large ulcer with an extensive area of exposed muscle

again revealed the filamentous bacteria. Mortalities and prevalence of the lesions diminished after 2 wk. A similar pattern of mortality and lesions occurred in other groups of smolts introduced in March and April of 1985, 1986, and 1987. Fish introduced later in the spring and summer exhibited lower post-introduction mortalities concurrent with a lower prevalence of the lesions.

Plasma sodium levels were determined in fish from the 1986 study pen at $13 \mathrm{~d}$ PI. Fish with skin lesions had significantly higher $(p<0.05)$ plasma sodium levels than unaffected fish (Student's t-test) (Table 1).

\section{Histological observations}

Tissue sections of lesions where the skin was present revealed accumulations of filamentous bacteria on the surface of the skin and throughout the epidermis and dermis. In more severely involved areas, large mats of 


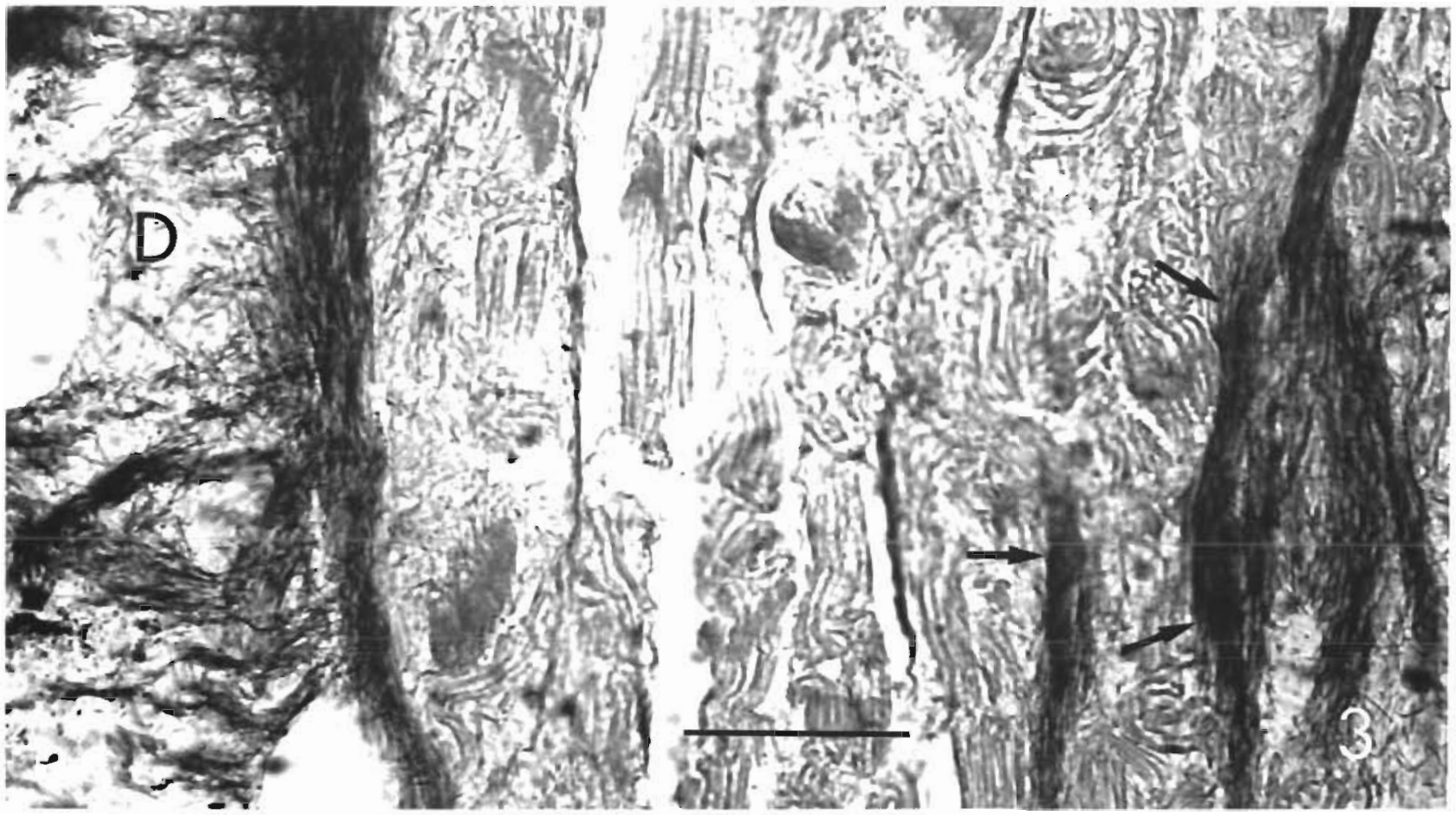

Fig. 3. Salmo salar. Histological section of affected skin and muscle. Note replacement of the dermis (D) with mats of filamentous bacteria and bacterial invasion of the underlying muscle (arrows). Hematoxylin \& eosin; bar $=50 \mu \mathrm{m}$

Table 1 Salmo salar. Plasma sodium levels in Atlantic salmon with Cytophaga-associated skin lesions and asymptomatic fish held in a seawater net pen. Fish were examined $13 \mathrm{~d}$ after introduction to seawater

\begin{tabular}{|ccrrr}
\hline \multirow{2}{*}{$\begin{array}{c}\text { No. fish. } \\
\text { sampled }\end{array}$} & $\begin{array}{c}\text { Presence of } \\
\text { skin lesions }\end{array}$ & \multicolumn{2}{c}{ Plasma sodium (mmol 1 } \\
& & SD & Range \\
\hline 5 & No lesions & 161 & 6 & $151-167$ \\
10 & With lesions & 206 & 14 & $183-228$ \\
\hline
\end{tabular}

filamentous bacteria replaced the dermis and the bacteria also occurred deep in the underlying musculature (Fig. 3). Affected muscle was hemorrhagic and necrotic, but little inflammation was observed. The bacterium was observed only in the muscle and skin; tissue sections of the gills and visceral organs revealed no bacteria or pathological changes.

\section{Bacterial characteristics}

Lesions from 8 fish were cultured on Marine Agar and seawater-Cytophaga Medium during the 1987 epizootic. After 3 d incubation, numerous bacterial colonies with a variety of morphologies were observed on all plates. However, the predominant isolates were $\mathrm{C}-\mathrm{F}$ bacteria. They consisted of small yellow colonies which were rhizoid on the Cytophaga Medium and smooth with entire margins on Marine Agar. Wet mounts of these colonies revealed long, filamentous bacteria. As the yellow colonies continued to grow it was evident, based on colony morphology, that they represented a single species of bacterium.

The bacterium was isolated in pure culture and examined further. Cells of the isolate, designated SF87$1 \dot{6} \mathrm{c}$, were Gram-negative, measured 0.5 to $0.7 \times 4$ to $20 \mu \mathrm{m}$, and exhibited gliding motility that was most prominent in young cultures. On Marine Agar the bacterium grew rapidly and typically produced cells shorter than $8.0 \mu \mathrm{m}$. The isolate was catalase-positive, oxidase-and flexirubin-negative, did not degrade agar, grew at 4 to $30^{\circ} \mathrm{C}$, and grew in Cytophaga Medium supplemented with 10 to $100 \%$ seawater. Observation of 3 -wk-old cultures revealed numerous sphaeroblasts but no microcysts. The isolate also exhibited a $\mathrm{G}+\mathrm{C}$ ratio of $34.5 \%$. Soluble antigen made from the isolate showed no cross-reactivity with Flexibacter columnaris and $F$. maritimus but a very weak preciptin band was formed against Cytophaga psychrophila. No bacteria were isolated from the kidney samples of fish with the skin and muscle lesions.

\section{Transmission}

Four of the 10 fish inoculated with SF87-16c developed severe skin and muscle lesions and died 4 to $8 \mathrm{~d}$. after exposure. Nine of the 10 fish inoculated with 
fresh tissue developed similar lesions and died 4 to $6 \mathrm{~d}$ after exposure. The surviving fish in these groups and the control fish did not develop the lesions and the area where the skin had been scraped eventually healed.

Filamentous bacteria with a colony color and morphology similar to that of SF87-16c were isolated from the lesions of 8 of the 9 mortalities in the tissuechallenged group and from 3 of the 4 mortalities in the bacteria-challenged group. One isolate from the latter group, designated Bact 4 , was further investigated and exhibited identical morphological, cultural, biochemi$\mathrm{cal}_{1}$ and serological characteristics to those previously described for isolate SF87-16c. The fish from which C-F bacteria were not reisolated yielded plates that were heavily overgrown with a variety of rapidly growing extraneous bacteria.

\section{DISCUSSION}

A Cytophaga-like bacterium, identified as a Cytophaga sp., was associated with mortalities in the Atlantic salmon following introduction to seawater in the spring of 1985, 1986, and 1987. As demonstrated in investigations of the 1986 epizootic, initial mortality was likely due to physical trauma because Cytophagaassociated lesions were not observed on moribund fish until 3 to $4 \mathrm{~d}$ PI. However, mortalities continued to be significant for approximately $3 \mathrm{wk}$ (Fig. 1) and all of the moribund or dead fish exhibited prominent skin lesions associated with the Cytophaga-like bacteria. Mortalities then diminished concurrently with a lower prevalence of skin lesions.

It is likely that the Cytophaga sp. in this study was the primary etiological agent of the disease. Although in-depth bacteriological studies on isolates from the skin lesions were conducted only on fish obtained from the 1987 epizootic, massive accumulations of filamentous Cytophaga-like bacteria were always observed in tissue sections and in wet mounts prepared from affected fish from all $3 \mathrm{yr}$. The transmission data are also supportive of Cytophaga sp. etiology because fish challenged with the isolate in this study (SF87-16c) developed severe lesions and died. Furthermore, bacteria with characteristics identical to those of SF87-16c were isolated from the lesions of the challenged fish. Cytophaga and Flexibacter spp. are often opportunistic pathogens and inconsistent results have often been obtained in transmission experiments in the laboratory (Pacha \& Ordal 1967, 1970, Campbell \& Buswell 1982, Wakabayashi et al. 1984). In the present experiment, only 4 of 10 fish exposed to isolate SF87-16c became infected and developed lesions, even though the skin was scarified and inoculated with heavy concentrations of the bacterium. In contrast, 9 of 10 fish developed the lesions when exposed to fresh lesion material. These results may indicate that the bacterium may not be highly virulent by itself and that other factors, such as synergistic bacteria on the skin, may enhance the infection. On the other hand, bacterial pathogens maintained on artificial media sometimes quickly lose their virulence, and this may have been a contributing factor to the low infection rate observed for isolate SF87-16c

Bacteriological and histological examinations of internal organs of affected fish indicated that the fish were not affected by other pathogens, but other factors may have predisposed the fish to the disease. The Cytophaga sp. associated with the lesions is a marine bacterium as indicated by its requirement of seawater for growth, and it is likely that the smolts were immunologically naive with respect to this bacterium when they were first introduced to seawater. Additionally, smoltification, transportation, and introduction to seawater cause elevated plasma cortisol levels (Specker \& Schreck 1980, Redding et al. 1984), which result in immunosuppression and render fish more susceptible to disease. Physical trauma during transport causes skin abrasions which may allow the bacteria to establish an infection, and preliminary observations indicated that improved transport techniques may reduce the prevalence of the disease. There appears to be a seasonality to the disease and fish introduced later in the spring and summer of 1986 exhibited fewer skin lesions.

The affected fish had elevated plasma sodium levels compared to those of fish without lesions (Table 1). Although plasma sodium levels were determined on only 5 unaffected fish in this study, we have found from an examination of over 100 Atlantic salmon smolts during their first summer in seawater that plasma sodium levels of healthy fish are consistently below $180 \mathrm{mmol}^{-1}$. The elevated plasma sodium levels in fish with skin and muscle lesions indicates that they may have ultimately died from an osmotic imbalance. Only sodium was analyzed for but presumably other ions (e.g. $\mathrm{Mg}^{++}$) were also elevated.

The taxonomy of bacteria in the order Cytophagales is still in a confused state (Reichenbach \& Dworkin 1981, Reichenbach 1988) and our isolate could not be identified to species level. Following criteria established by Reichenbach \& Dworkin (1981), we placed our isolate in the order Cytophagales: it was a unicellular, Gram-negative, rod-shaped, gliding bacterium that failed to produce fruiting bodies. In addition, the isolate appeared to belong to the genus Cytophaga. Unlike members of the other genera within the order Cytophagales, it failed to produce microcysts (cf. the genus Sporocytophaga), it grew aerobically (cf. the Sphaerocytophaga/Capnocytophaga), it produced cells that 
were usually less than $20 \mu \mathrm{m}$ in length (cf. the genera Flexibacter and Microscilla), and its $\mathrm{G}+\mathrm{C}$ mole ratio was $34.5 \%$ (cf. the genus Lysobacter in which the corresponding value is 65 to $68 \%$ ) (Reichenbach \& Dworkin 1981, Reichenbach 1988).

Serological tests showed that it is distinct from the 3 recognized fish pathogenic $\mathrm{C}-\mathrm{F}$ bacteria: Flexibacter maritimus, F. columnaris, and Cytophaga psychrophila. Additionally, our isolate differs from the 2 last-named organisms (both freshwater pathogens) in its requirement of seawater for growth. It also differs from $F$. maritimus in its ability to grow at lower temperatures. The Cytophaga sp. of the present study is likely an undescribed species and further biochemical tests and DNA hybridizations are needed to characterize it more completely before naming it.

The diseases in salmonids reported by Borg (1960) and Wood (1974) are similar to the disease reported here because the salmon smolts were affected only after introduction to seawater and because large caudal peduncle ulcerations were a common gross pathological change. Borg (1960) and Wood (1974) attributed the disease to a Sporocytophaga sp. based on the presence of microcysts. However, they did not clearly differentiate these from sphaeroblasts. There is a possibility that the diseases reported by Borg (1960) and Wood (1974) were caused by the same Cytophaga sp. described here, but without in-depth biochemical studies or serological comparison of their isolates this cannot be determined. Our attempts to obtain their 'Sporocytophaga' isolates have been unsuccessful.

Many C-F diseases occur in cultured marine fishes but seldom are the bacteria isolated, adequately characterized, or made available for taxonomic studies. Until these shortcomings are made up, knowledge on the C-F bacteria pathogenic to marine fishes will be slow to develop.

Acknowledgements. The Battelle Marine Research Laboratory is part of the Pacific Northwest Laboratories and is operated for the US Department of Energy by the Battelle Memorial Institute under contract DE-AC06-76RLO 1830. Funding was also provided by Battelle Memorial Institute, Corporate Technical Development Project Number B-0322-4051, Columbus, Ohio, USA. This study was supported in part by Battelle Memorial Institute (BMI), Columbus, Ohio. We thank the staff of Sea Farm of Washington for their assistance and cooperation, A. Drum for assistance with bacterial preparations, and M. Wilkinson for histological preparations

\section{LITERATURE CITED}

Anacker, R. L., Ordal, E. J. (1959). Studies on the myxobacterium Chondrococcus columnaris I. Serological typing. I. Bacteriol. 78: 25-32

Anderson, J. I. W. Conroy, D. A. (1969). The pathogenic myxobacteria with special reference to fish diseases. $J$ appl. Bact. 32: 30-39
Baxa, D. V., Kawai, K., Kusuda, R. (1986). Characteristics of gliding bacteria isolated from diseased cultured flounder. Paralichthys olivaceous. Fish Pathol. 21. 251-258

Baxa, D. V., Kawai, K. Kusuda, R. (1987), Experimental infection of Flexibacter manitimus in black sea brean (Acanthopagrus schlegeli) fry. Fish Pathol. 22: 105-109

Becker, C. D., Fujihara, M. P. (1978). The bacterial pathogen Flexibacter columnaris and its epizootiology among Columbia River fish. Monograph No. 2, Am. Fish. Soc., Washington, D.C

Borg, A. (1960). Studies on myxobacteria associated with diseases in salmonid fishes. Wildl. Dis. (microfiche) 8: 1-85 (2 microcards)

Campbell, A. C., Buswell, J. A. (1982). An investigation into the bacterial aetiology of 'black patch necrosis' in Dover sole. Solea solea L. J. Fish Dis. 5: 495-508

Elston, R., Elliot, E. L., Colwell, R. R. (1982). Conchiolin infection and surface coating Vibrio: shell fragility, growth depression and mortalities in cultured oysters and clams Crassostrea virginica, Ostrea edulis and Mercenaria mercenaria. J. Fish Dis. 5: 265-284

Hikida, M., Wakabayashi, H., Egusa, S., Masumura, K. (1979). Flexibactersp., a gliding bacterium pathogenic to some marine fishes in Japan. Bull. Jap. Soc. scient. Fish. 45: 421-428

Humason, G. L. (1979). Animal tissue techniques. W. H. Freeman Co., San Francisco

Johnson, J. L. (1981). Genetic characterization. In: Gerhardt, P. (ed.) Manual of methods for general bacteriology. Am. Soc. Microbiol., Washington. D.C., p. 450-472

Masumura, K., Wakabayashi, H. (1977). An outbreak of gliding bacterial disease in hatchery-born red seabream (Pagrus major) and gilthead (Acanthopagrus schlegeli) fry in Hiroshima. Fish Pathol. 12: 171-177

Pacha, R. E., Ordal, E. J. (1967). Histopathology of experimental columnaris disease in young salmon. J. comp. Pathol. 77: 419-423

Pacha, R. E., Ordal, E. J. (1970). Myxobacterial diseases of salmonids. In: Sniesko, S. F. (ed.) A symposium on diseases of fishes and shellfishes. Special Publ. No. 5., Am. Fish. Soc., Washington, D.C., p. 243-257

Redding, J. M., Schreck, C. B., Birks, E. K., Ewing, R. D. (1984). Cortisol and its effects on plasma thyroid and electrolyte concentrations in fresh water and during seawater acclimation in yearling coho salmon, Oncorhynchus kisutch. Gen. comp. Endocrinol. 56: 146-155

Reichenbach, H. (1988). Section 23, Genus Cytophaga. In: Holt, J. G., Staley, J. T., Bryant, M. P., Pfennig, N. (eds.) Bergey's manual of systematic bacteríology, Vol. 3. Williams \& Wilkins, Baltimore (in press)

Reichenbach, H., Dworkin, M. (1981). The order Cytophagales (with addenda on the genera Herpetosiphon, Saprospira and Flexithrix). In: Starr, M. P., Stolp, H., Trüper, H. G., Balows, A, Schlegel, H. G. (eds.) The prokaryotes. Springer-Verlag, New York, Berlin, p. 356-378

Rucker, R. R. (1963). Status of fish diseases and relation to production. Rep. 2nd Governor's Cont on Pacific Salmon, Seattle, Jan 1963, p. 98-101

Sawyer, E. S. (1976). An outbreak of myxobacterial diseases in coho salmon (Oncorhynchus kisutch) reared in a Maine estuary. J. Wildl. Dis. 12: 575-578

Smibert, R. M. Krieg, N. R. (1981). General characterization. In: Gerhardt, P. (ed.) Manual of methods for general bacteriology. Am. Soc. Microbiol., Washington, D.C., p. 409-443

Sniesko, S F., Bullock, G. L. (1976). Columnaris disease of fishes. Fish Disease Leaflet 45. US Department of Interior, US Fish and Wildlife Service, Washington, D.C.

Specker, J. L., Schreck, C. B. (1980). Stress responses to 
transportation and fitness for marine survival in coho salmon (Oncorhynchus kisutch) smolts. Can. J. Fish. Aquat. Sci. 37: 765-769

Wakabayashi, H., Hikida, M., Masumura, K. (1984). Flexibacter infection in cultured marine fish in Japan. Helgoländer Meeresunters. 37: 587-593
Wakabayashi, H., Hikida, M., Masumura, K. (1986). Flexibacter maritimus sp. nov., a pathogen of marine fishes. Int. J. syst. Bacteriol. 36 : 396-398

Wood, J. (1974). Diseases of Pacific salmon; their prevention and treatment. Dept. Fish, Olympia, Washington

Responsible Subject Editor: Dr T Evelyn; accepted for printing on April 6, 1988 